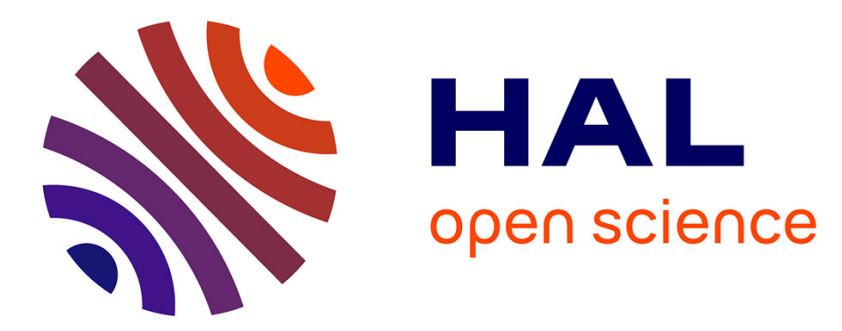

\title{
Organization of Sales for Smart Product Service Systems
}

Benedikt Moser, Achim Kampker, Philipp Jussen, Jana Frank

\section{To cite this version:}

Benedikt Moser, Achim Kampker, Philipp Jussen, Jana Frank. Organization of Sales for Smart Product Service Systems. IFIP International Conference on Advances in Production Management Systems (APMS), Sep 2019, Austin, TX, United States. pp.518-526, 10.1007/978-3-030-30000-5_64 . hal-02419243

\section{HAL Id: hal-02419243 \\ https://hal.inria.fr/hal-02419243}

Submitted on 19 Dec 2019

HAL is a multi-disciplinary open access archive for the deposit and dissemination of scientific research documents, whether they are published or not. The documents may come from teaching and research institutions in France or abroad, or from public or private research centers.
L'archive ouverte pluridisciplinaire HAL, est destinée au dépôt et à la diffusion de documents scientifiques de niveau recherche, publiés ou non, émanant des établissements d'enseignement et de recherche français ou étrangers, des laboratoires publics ou privés.

\section{(c)(1)}

Distributed under a Creative Commons Attribution| 4.0 International License 


\title{
Organization of Sales for Smart Product Service Systems
}

\author{
Benedikt Moser ${ }^{1}$, Achim Kampker ${ }^{1}$, Philipp Jussen ${ }^{1}$, Jana Frank ${ }^{1}$ \\ ${ }^{1}$ Institute for Industrial Management (FIR) at RWTH Aachen University, \\ Campus-Boulevard 55, 52074 Aachen \\ Benedikt.Moserefir.rwth-aachen.de
}

\begin{abstract}
Many industrial companies face their digital transformation. In addition to an existing portfolio of products and services, new digital services are being developed to offer a portfolio of smart product service systems (Smart PSS). While the development of new digital services is rarely a problem for the companies, the organization of sales and distribution of Smart PSS in particular is a key issue. The sales of Smart PSS differs considerably from the sales of only products or services and must therefore be designed differently in order to meet customer requirements and successfully commercialize the developed Smart PSS. This paper therefore describes how the sales organization of Smart PSS should be designed successfully in various forms. The network thinking methodology is used in combination with a case study research approach to describe the connection between the offered portfolio, the customer requirements and the different elements of a sales organization. Furthermore, four different types of a sales organization for Smart PSS are described. This paper gives a recommendation for companies on a design of their sales organizations on which practical implications may be developed.
\end{abstract}

Keywords: Smart Product Service Systems, Sales Organization, Sales Management, Network Thinking, Case Study Research

\section{Introduction}

Many industrial companies today already use a service business to differentiate themselves from competitors in the product business. They use the combination of products and services to offer systems that provide the customer a solution. Research literature refers to this as product service systems [1][2][3][4]. In addition, companies start to develop digital services [5][6]. Digital services use data as a central resource, e. g. data from the sensors of machines [7][8][9][10]. Manufacturing companies are trying to avoid the strong price competition in traditional product markets by offering digital solutions in addition to services, such as condition monitoring, remote services or value-added services [3][11][12]. The interplay between physical products, services and digital services is shown in the shell representation of Smart PSS (fig. 1) [13]. For many manufacturing companies, the physical product is still at the center of the portfolio. This is accompanied by a complementary business of spare parts and an expanded product range. 


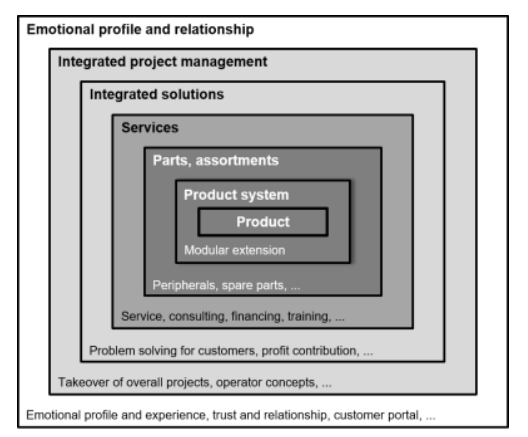

Fig. 1. Shell illustration of product service systems [13]

In the fourth shell, classic services are added, which complement the product business to form a product service system. Although the following shells only describe a deeper integration of the system, many of the digital solutions make it possible to establish the deep integration to offer a Smart PSS [13][14][15][16].

However, many companies struggle to sell Smart PSS. Studies about companies, which offer only product service systems, show that even they struggle to sell the solutions properly [17]. Referring to case studies we conducted for this paper, companies also struggle to sell Smart PSS properly. A first indicator of why these companies have problems is provided by a study showing that 39 percent of the surveyed top performing companies set up their own sales department to sell digital services [18]. Although this step seems logical at first in order to transfer the speed from the development process into sales, problems arise during integration with sales for existing products and services [19]. The design of Smart PSS follows the same principles as for PSS [20]. This includes the integration of the system in order to create synergies [21][22], and the oneface-to-the-customer principle, which describes that there should be a single point of contact for every customer [16]. The current division of the sales departments into products, services and digital solutions leads to a one-sided focus in which each department optimizes itself and to individual customer contact persons for products, services and digital solutions [18].

This gap between the design principles and business practice is the motivation for this paper. Many companies invest large sums in the development of Smart PSS, but seem to have problems in the distribution of those systems. Due to the lack of research in this area, we aim to provide new insights in this paper to describe the relevant elements of a sales organization and to describe possible characteristics for different types of Smart PSS. In order to achieve this, the paper addresses the following research question: How can the sales organization of smart product service systems be designed successfully?

To answer this question we first briefly summarize the theoretical background of the relevant literature. Second, we describe the research methodology that was used to identify the elements of a sales organization for Smart PSS. Third, we present the results of the developed model with regard to the research question. Fourth, we conclude with the key contributions of this work to the field of sales organizations for Smart PSS. 


\section{Research Background}

\subsection{Smart Product Service Systems}

The term 'smart product service systems' is quite new to research literature and therefore has to be described in detail before dealing with it in the following. CHOWDHURY ET AL. deliver an in deep systematic literature review on the term of Smart PSS [23]. They present in detail, that most of the work done in the field covers product service systems, but little effort was put in conceptualizing the 'smart' aspect of the PSS. The 'smart' aspect is often implied in the definition of these systems, but there a no distinct answers given to how PSS can be enabled to get 'smart'. VALENCIA ET AL. describe three general types of PSS: result-oriented, use-oriented and product-oriented. Furthermore, they answer to how PSS are getting 'smart'. "Smart PSSs are 'smart' because they carry some of the characteristics of smart products, such as the capacity to transform data into knowledge to perform more effectively" [20]. There is not one sole definition covering all aspects necessary for a satisfying characterization. However, as CHOWDHURY ET AL. deliver the most recent definition, it is likely the most sophisticated. The basis for their definition are the interactions of smart technologies, physical products, services and business models. Common to all previous literature the main goal is to satisfy the customers' needs [14][20][23]. This satisfaction is reached through functional integration of digital services [34][35].

\subsection{Sales Organization}

The sales organization is a functional department of a business that is responsible for the sale of the portfolio offerings and the design of the distribution channels. Therefore, it may be seen as a tool of the distribution policy. Further, a comprehensive and complete task description is harder to conceptualize, because of the different scope in each individual business [24]. Most literature is dealing with characteristic approaches to sales of products alone. On the one hand, there are approaches, which may be transferable and applicable for Smart PSS. On the other hand, the Smart PSS alter from the common approaches in a way that these concepts have to be revisited and thought through again [25]. The sale and distribution of Smart PSS have a strong focus on business-to-business markets. Thus, customers are mostly businesses as well, which leads to other characteristic behaviours compared to Business-to-customer customers [26].

\section{Methodology}

The design of the sales organizations for smart product service systems followed an iterative five-step approach, which is based on the methodology of network thinking as shown in Fig. 2 [27][28]. Designing a successful sales organization for Smart PSS is a complex problem. A tool for mastering this complexity is the method of networked thinking. The goal of networked thinking is to describe cause-effect relationships in systems in such a way that the behavior of the system becomes predictable under 
changed conditions. In particular, the method makes it possible to map and analyze the type, intensity and time behavior of the interrelationships between the individual system descriptive characteristics [27][28][29][30].

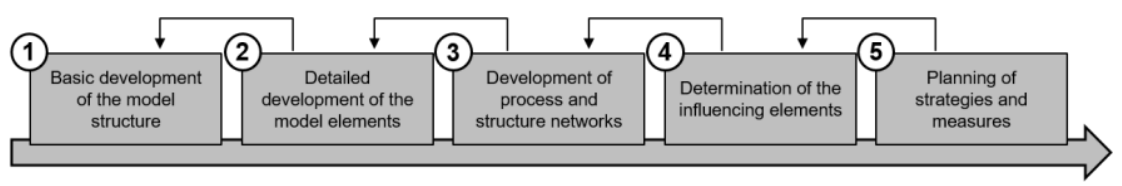

Fig. 2. Approach of Network Thinking for the development of sales organizations

The research in this paper is limited to steps 1 and 3 of the process. For this purpose, the basic model elements were described by means of a case study research approach. This method is suitable whenever a theory for a so far unknown phenomenon is to be built [31][32]. Case study research ensure that the achieved results are closely connected to the everyday reality of companies. To record the case studies a standardized interview was conducted with managers from the sales and product management departments. In table 1 all recorded use-cases are listed. The number of case studies examined for this paper is limited to five, as the elements of the developed model and the different types of sales organizations were the same for all companies. Even though the focus of this paper is on machine manufacturers, we also included cases from neighboring industries in the study to gain a holistic view of the sales organization.

Table 1. Overview of selected cases

\begin{tabular}{|l|l|l|l|l|}
\hline Industry & Employees & Turnover & Sales organization & Type \\
\hline Agricultural machinery & 11.500 & $€ 3.7 \mathrm{bn}$ & Integrated & OEM \\
\hline Equipment manufacturer & 6.000 & $€ 1.5 \mathrm{bn}$ & Separated & OEM \\
\hline Machine manufacturer & 13.500 & $€ 3.5 \mathrm{bn}$ & Integrated & OEM \\
\hline Equipment dealer & 3.000 & $€ 1.1 \mathrm{bn}$ & Integrated & Supplier \\
\hline Equipment manufacturer & 1.700 & $€ 280 \mathrm{mio}$ & Separated & OEM \\
\hline
\end{tabular}

\section{Sales Organization for Smart Product Service Systems}

In this section, the results of the case study research are presented. First, the typical elements of a sales organization for Smart PSS and their connection will be discussed. Afterwards, different types of sales organizations and their effects on the aspects of the organization will be presented.

\subsection{Elements of a sales organization for smart product service systems}

Based on the conducted interviews from the case study research with five companies the following basic model of a sales organization for Smart PSS was derived through network thinking (fig. 3). The model is based on the interviews and the connections between the different elements. The interrelationships were collected with the help of networked thinking. The model is divided in four main sections, which are interconnected with each other. 


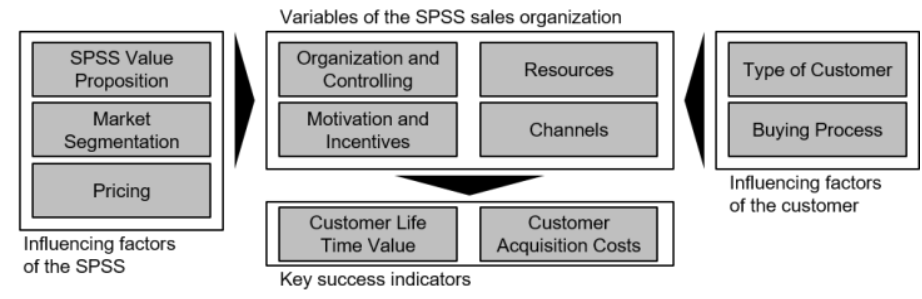

Fig. 3. Basic model elements of a sales organization for Smart PSS and their connection

The variables of the sales organization of a Smart PSS are at the center of the model, which includes 'organization and controlling', 'resources', 'motivation and incentives' and 'channels'. These elements are also described in the literature as typical elements of a sales organization [25][26]. Two sections are influencing these variables of the sales organization. This is on the one hand the influencing factors of the Smart PSS itself with the elements 'Smart PSS value proposition', 'market segmentation' and 'pricing' and on the other hand, the influencing factors from the customer side with the elements 'type of customer' and 'buying process'. To measure the success of the Smart PSS sales organization companies use the key success indicators 'customer life time value' and 'customer acquisition costs'. These two indicators already show that companies want to minimize the costs to convince a new customer of the Smart PSS and try to increase the perceived value of the Smart PSS during a longer time following the long-term principle of PSS [16].

This basic model already shows the complexity of the design of a sales organization for Smart PSS. Especially the two influencing sectors have in combination a huge impact on the sales organization. The Smart PSS portfolio is usually developed independently from the sales organization and different types of market segments and types of customers want differently be addressed by a sales organization [24], which is also acknowledged in the next chapter by the description of different types of a sales organization for Smart PSS. The complexity of the model arises from the interaction of the individual elements, since they are of different intensity and time behavior. The change in the organizational structure, for example, can be changed quickly, while the culture and cooperation of the employees are rather slow elements.

\subsection{Different types of sales organization for smart product service systems}

The case studies show that, depending on the current Smart PSS portfolio and the company's customers, there are different types of sales organization. A total of four of these types are shown in fig.4. In the first type, the offering is divided into three categories (product, service, digital), of which all are sold separately. The second type integrates the respective service and digital departments, as both work from a customer-centric perspective [18]. The third type offers Smart PSS for the first time, but as a bundle with individual revenue models [13][16]. The last stage represents a subscription model for the entire Smart PSS, where the entire service is sold via a subscription model in the digital ecosystem [33]. 


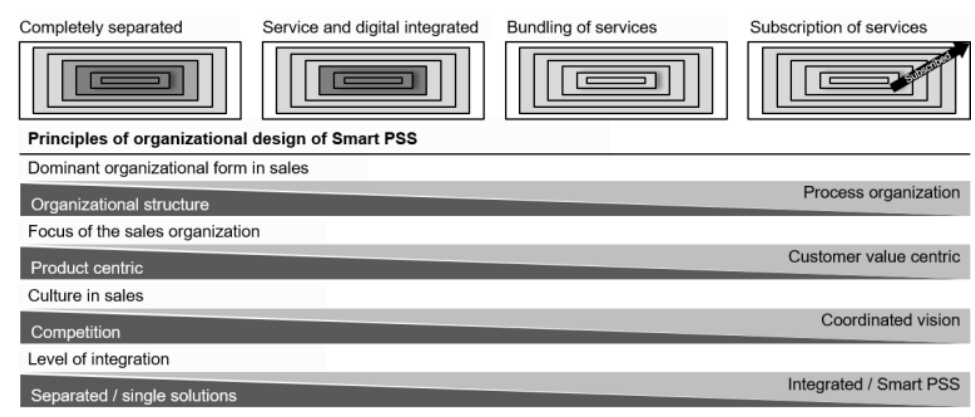

Fig. 4. Different types of sales organizations for Smart PSS

The fundamental aspects of a sales organization are changing. These include the dominant organizational form, the focus of the organization, the culture and the level of integration. All four aspects are changing from a rather separate and non-integrated to an organization whose aim is to jointly sell Smart PSS. In addition to the mere organization or processes, softening factors such as the culture of the employees are also a decisive changing factor, which show the complexity of the whole research and application field. The sales organization must be able to fulfill all four characteristics, as the case study research shows that there are customer groups for each type of business model. This finding, together with the already prevailing complexity described in the previous section, shows that the sales organization for Smart PSS needs to be completely rethought and -designed to ensure successful sales and to respond to the needs of customer groups of Smart PSS.

\section{$5 \quad$ Contribution and Discussion}

The literature examined show that companies have few problems with the technical development of Smart PSS, but the sale leads to major problems. This happens due to the high complexity, which Smart PSS as well as different customer groups put to the sales organization. The contribution of this paper is a model that illustrates the complexity of sales organizations by presenting the individual elements in a first draft model. In addition, the demand is shown that the future Smart PSS sales organization is designed by different types in order to successfully serve various customer groups.

The results of the paper provide an initial contribution to understanding the complexity of the sales organization, which lead to recommendations for companies for the optimal design of their sales organization. Nevertheless, this paper can only provide a basic model for the sales organization, but is the first of its kind to focus on the sales organizations while other authors usually focus on the portfolio or development of Smart PSS [36]. Next steps are to detail the individual elements and to gain a deeper understanding of the intensity and time relationships of the elements described in fig. 3. Based on the resulting dynamic model of the Smart PSS sales organization, influencing variables can be determined that could be changed better or worse. Based on these influencing variables, recommendations for action can be developed, which transfer the 
findings of the theoretical model of a sales organization for Smart PSS into design guidelines applicable for companies. In order to carry this out, both extensive research on Smart PSS, as well as the inclusion of further case studies is necessary.

\section{References}

1. Gebauer, H., Guang-Jie, R., Valtakoski, A., Reynoso, J.: Service-driven manufacturing. Journal of Service Management 1, 120-136 (2012).

2. Gustafsson, A., Grönroos, C., Helle, P.: Adopting a Service Logic in Manufacturing: Conceptual Foundation and Metrics for Mutual Value Creation. Journal of Service Management 21, 564-90 (2010).

3. Herterich, M., Uebernickel, F., Brenner, W.: Stepwise Evolution of Capabilities for Harnessing Digital Data Streams in Data-Driven Industrial Services. MIS Quarterly Executive 4, 297-318 (2016).

4. Lightfoot H, Baines T, Smart P.: The Servitization of Manufacturing: A Systematic Literature Review of Interdependent Trends. International Journal of Operations \& Production Management 5, 547-567 (2009).

5. Kagermann, H., Riemensperger, F., Hoke, D., Schuh, G., Scheer, A. W. (eds.): Smart Service World: Recommendations for the strategic initiative 'web-based services for business'. acatech - Deutsche Akademie der Technikwissenschaften, Berlin (2015).

6. Schuh, G., Anderl, R., Gausemeier, J., ten Hompel, M., Wahlster, W. (eds.): Industrie 4.0 Maturity Index: Managing the Digital Transformation of Companies. Herbert Utz Verlag, München (2017).

7. Bullinger, H.-J., Meiren, T., Nägele R.: Smart services in manufacturing companies. In: 23rd International Conference on Production Research, pp. 7-13, ICPR, Manila (2016).

8. Oliveira, P., Roth, A. V.: The Influence of Service Orientation on B2B e-Service Capabilities: In: Production and Operations Management 3, 423-443 (2012).

9. Lee, J., Hung-An, K., Shanhu Y.: Service Innovation and Smart Analytics for Industry 4.0 and Big Data Environment. In: Procedia CIRP, pp. 3-8 (2014).

10. Kampker, A., Jussen, P., Moser, B.: Industrial Smart Services: Types of Smart Service Business Models in the Digitalized Agriculture. In: Proceedings of the 2018 IEEE International Conference on Industrial Engineering and Engineering Management (IEEM), 1081-1085. IEEE, Bangkok (2018).

11. Huang, M.-H., Rust, R. T.: IT-Related Service: A Multidisciplinary Perspective. Journal of Service Research 3, 251-258 (2013).

12. Paluch, S., Wünderlich, N. V.: Contrasting Risk Perceptions of Technology-Based Service Innovations in Inter-Organizational Settings. In: Journal of Business Research, 7, 2424-2431 (2016).

13. Belz, C., Schuh, G., Groos, S. A., Reinecke, S.: Erfolgreiche Leistungssyteme in der Industrie. In: Belz, C., Tomczak, T., Weinhold-Stünzei, H. (eds.): Industrie als Dienstleister, 14109. Thexis Verlag, St. Gallen (1997).

14. Porter, M. E., Heppelmann, J. E.: How smart, connected products are transforming competition. Harvard business review 92(11), 64-88 (2014).

15. Allmendinger, G., Lombreglia, R.: Four strategies for the age of smart services. Harvard business review 83(10), 1-11 (2005).

16. Schuh, G., Gudergan, G., Senderek, R., Wagner, D.: Leistungssysteme. In: Schuh, G., Gudergan, G., Kampker, A. (eds.): Management industrieller Dienstleistungen. Zweite Auflage, 1-20. Springer, Berlin (2016). 
17. Dachs, B., Biege, S., Borowiecki, M., Ley, G., Jäger, A., Schartinger, D.: Servitisation of European manufacturing: evidence from a largescale database. In: The Service Industries Journal, 34(1), 5-23 (2014).

18. Kampker, A., Frank, J., Schwartz, M., Jussen, P.: Lernen von den Besten: Fünf Erfolgsfaktoren bei der Entwicklung von Smart Services. In: Meyer, K., Klingner, S., Zinke, C. (eds.): Service Engineering. Von Dienstleistungen zu digitalen Service-Systemen, 151-166. Springer, Berlin (2018).

19. Ulaga, W., Reinartz, W.: Hybrid Offerings: How Manufacturing Firms Combine Goods and Services Successfully. In: Journal of Marketing 75, 5-2 (2011).

20. Valencia, A., Mugge, R., Schoormans, J., Schifferstein, H.: The Design of Smart ProductService Systems (PSSs): An Exploration of Design Characteristics. In: International Journal of Design 9, 13-28 (2015).

21. Haedrich, G., Tomczak, T. (eds.): Produktpolitik. Kohlhammer, Stuttgart (1996).

22. Luczak, H. (eds.): Servicemanagement mit System - erfolgreiche Methoden für die Investitionsgüterindustrie. Springer, Berlin (1999).

23. Chowdhury, S.; Haftor, D.; Pashkevich, N.: Smart Product-Service Systems (Smart PSS) in Industrial Firms: A Literature Review. In: Procedia CIRP 73, 26-31 (2018).

24. Homburg, C., Schäfer, H., Schneider, J. (eds.): Sales Excellence, Systematic Sales Management. Springer, Berlin (2012).

25. Geissbauer, R., Griesmeier, A., Feldmann, S., Toepert, M. (eds.): Serviceinnovation. Potenziale industrieller Dienstleistungen erkennen und erfolgreich implementieren. Springer, Berlin (2012)

26. Kampker, A., Husmann, M., Jussen, P., Schwerdt, L.: Market Launch Process of DataDriven Services for Manufacturers: A Qualitative Guideline. In: Satzger, G., Patricio, L., Zaki, M., Kühl, N., Hottum, P. (eds.): Exploring Service Science. 9th International Conference, IESS 2018, Karlsruhe, Germany, Proceedings, 177-189 (2018).

27. Probst, G. J. B., Gomez, P. (eds.): Die Praxis des ganzheitlichen Problemlösens. Gabler, Wiesbaden (1997).

28. Probst, G. J. B., Gomez, P. (eds.): Vernetztes Denken - ganzheitliches Führen in der Praxis. Gabler, Wiesbaden (1991).

29. Berninghaus, H., v. Bogdandy, C.: Management komplexer Zusammehänge durch systemisches Denken. In: Industrie Management 13(6), 55-59 (1997).

30. Vester, F.: Die Kunst vernetzt zu denken. DVA, Stuttgart (2000).

31. Eisenhardt, K. M.: Building Theories from Case Study Research. Academy of Management Review 14(4), 532-50 (1989).

32. Eisenhardt K. M., Graebner M. E.: Theory Building from Cases: Opportunities and Challenges. Academy of Management Journal 50(1), 25-32 (2007).

33. Tzuo, T.: Subscribed. Why the Subscription Model Will Be Your Company's Future - and What to Do About it. Portfolio/Penguin, New York (2018).

34. Zheng P., Lin T-J., Chen C-H., Xu X.: A systematic design approach for service innovation of smart product-service systems. In: Journal of Cleaner Production (2018).

35. Ardolino M., Rapaccini M., Saccani N., Gaiardelli P., Crespi G., Ruggeri C.: The role of digital technologies for the service transformation of industrial companies. In: International Journal of Production Research (2017).

36. Raddats, C., Kowalkowski, C., Benedettini, O., Burton, J.,Gebauer, H.: Servitization: A contemporary thematic review of four major research streams. In: Industrial Marketing Management (2019). 